\title{
Measuring Students' Satisfaction with Implementing a Student' Centered Seminar at Problem-Based Learning, the Faculty of Medicine - Suez -Canal University
}

\author{
Marwa Ahmed $\mathrm{AE}^{1 *}$, Wagdy $\mathrm{TY}^{2}$, Refaat $\mathrm{AH}^{3}$ and El- Din Ahmed RAG
}

${ }^{1}$ Medical Education Department, Faculty of Medicine, Dubai Medical Collage for Girls, UAE

${ }^{2}$ Professor of Pathology, Faculty of Medicine, Suez Canal University, Ismailia, Egypt

${ }^{3}$ Professor of community medicine, Faculty of Medicine, Suez Canal University, Ismailia, Egypt

${ }^{4}$ Professor of microbiology, Faculty of Medicine, Suez Canal University, Ismailia, Egypt

\begin{abstract}
Background: Seminar is one of the educational resources in PBL; it is a form of academic teaching, normally at a university where students are requested to actively participate during meetings. This often has to be done in the presence of an issue under investigation or research. Often a seminar will be open to discussion, often questions can be raised and debates conducted.
\end{abstract}

Aim: The aim of this study was to measure students' satisfaction with implementing a student's centered seminars and comparing students' satisfaction by using students centered and teachers centered seminars.

Materials and Methods: The study was a comparative one. Simple random sampling from Phase III students (4th, 5th and 6th year students) was selected a total number of 163 Students. A Self - administered questionnaires for phase III students was distributed; measuring their satisfaction according two methods of implementing seminar; students centered and teacher centered one. SPSS software was used for the purpose of statistical analysis. Comparisons between students' satisfaction were made using T-test (comparative statistics).

Results: $42 \%$ of the sample group said that they most of the time are keen to attend the seminar because of its importance to their understanding to solve the problem. $21 \%$ of the sample group said that seminar is conducted in a discussion form most of the time. Students acquired new skills by applying the new innovative approach in conducting seminars. There is statistically significant difference ( $p$-value $<0.0001)$ between two methods regarding students' acquisition of leadership skill, presentation skill and communication skills. There is statistically significant difference ( $p$-value $<0.0001$ ) between two methods regarding students' ability to Search in the internet, Express their points of view, and Use additional educational resources. Sixteen percent of the students learned by the students centered method of seminar agreed that their presentation in the seminar should be evaluated and be part of their summative assessment. Thirty nine percent of the students learned by the students centered method of seminar agreed that changing the current method of conducting seminar into on line seminar will be better.

Conclusion: Study conclude that the students generally preferred the students centered method of conducting the seminar more than the teacher centered one as they fell more responsibility for it, and more actively involved in it, also they are active learner, they search for the updated information related to the theme of the problem try together to work in a team, benefit from each other and using their skills and abilities to present the weekly problem in a competitive, challenging spirit between them.

Keywords: PBL; Educational resources; students' centered seminar; Students satisfaction; Kirkpatrick

\section{Introduction and Rational}

Problem-Based Learning has been defined as "an educational method which uses carefully constructed clinical problems as a context for students to learn problem solving skills and acquire knowledge about the basic and clinical science" [1].

Problem-Based Learning (PBL) is a pedagogical strategy for posing significant, contextualized, real world situations, and providing resources, guidance, and instruction to learners as they develop content knowledge and problem-solving skills [2]. It is a studentcentered, collaborative, nontraditional approach to education that was first implemented in medical education at McMaster's University in 1965 [3]. It represents a major, complex and widespread change in educational practice within higher education, especially in Professional education. Many medical schools from all over the world have implemented PBL [4].

Problem-Based Learning is characterized by certain ground rules. It is a combination of educational methods and philosophy.
Philosophically, PBL is centered on the student and on problemfirst learning, whereas in subject-based learning teachers transmit knowledge to students before using problems to illustrate it [5]. Through $\mathrm{PBL}$, students learn how to use an iterative process of assessing what they know, identifying what they need to know, gathering information, and collaborating on the evaluation of hypotheses in light of the data. Problem-based Learning has become a popular method of instruction

*Corresponding author: Marwa Ahmed AE, Medical Education Department, Faculty of Medicine, Dubai Medical Collage for Girls, UAE, Tel: 0567521594; E-mail: marwanagar@yahoo.com

Received December 18, 2013; Accepted January 20, 2014; Published January 27, 2014

Citation: Marwa Ahmed AE, Wagdy TY, Refaat AH, El- Din Ahmed RAG (2014) Measuring Students' Satisfaction with Implementing a Student' Centered Seminar at Problem-Based Learning, the Faculty of Medicine - Suez -Canal University. Intel Prop Rights 2: 111. doi:10.4172/2375-4516.1000111

Copyright: (c) 2014 Marwa Ahmed AE, et al. This is an open-access article distributed under the terms of the Creative Commons Attribution License, which permits unrestricted use, distribution, and reproduction in any medium, provided the original author and source are credited. 
Citation: Marwa Ahmed AE, Wagdy TY, Refaat AH, El- Din Ahmed RAG (2014) Measuring Students' Satisfaction with Implementing a Student' Centered Seminar at Problem-Based Learning, the Faculty of Medicine - Suez -Canal University. Intel Prop Rights 2: 111. doi:10.4172/23754516.1000111

Page 2 of 6

among educators in the health professions. Central to the effectiveness of PBL is the ability of students to work together to solve problems [6].

One of the fundamental concepts of the educational process in the Faculty of Medicine, Suez Canal University (FOM -SCU) is that the student is the pivot of his or her own learning process. In problem based learning whether in classes, field work or hospital, it is the student who determines which information or skills are needed to solve the addressed problems. At first, the tutors guide their students so that they acquire the necessary experience for determining learning objectives. Gradually, the student takes over the whole responsibility for specification of knowledge and skills conductive to achievement of educational objectives. This method motivates students and gives them a positive role in the educational process, they search and investigate through reading books and references, consulting with subject area experts, using audio-visual and computer sources as well as attending some lectures and seminars and practice of different examination skills. This active approach helps students retain their knowledge and skills, recall and apply them in a better way than if acquired passively [7].

\section{Educational resources supporting PBL}

For each educational problem, learning objectives are identified and agreed upon. Students then collect needed information from a variety of resources, including the library, the laboratory, other students, and faculty members. After initial information further learning objectives may be identified, and information gathering continues as needed throughout the problem [8].

Problem-Based Learning curriculum emphasizes the development of self-regulating skills. Rather than being passive recipients of information, students are expected to be actively involved [9].

\section{Seminar as a learning resource}

In addition to the conventional learning resources like the laboratories and the pre-set lectures, FOM-SCU students have other resources like seminars.

Definitions of Seminar: The seminar is a way of discussion. It consists of a panel comprising 5-6 persons: usually experts and an audience who is interested in the issue under discussion. The seminar is coordinated and run by a moderator, whose first job is to declare the date, time and place of the seminar and then to choose the suitable panel carefully [10] A seminar is a form of academic teaching, normally at a university where student are requested to actively participate during meeting. This often has to be done in the presence of an issue under investigation or research .Often a seminar will be open to discussion, often questions can be raised and debates conducted; definition given by dictionary Six Sigma Dictionary [11]. In seminar, student and subject matter experts interaction takes place more readily, to cover material in more depth or to provide additional vicarious learning experiences [12].

The term "seminar" is generally used in further education to refer to a structured group discussion which may follow a formal lecture, or which is introduced by the presentation of a thesis, often in the form of an essay .It specialist nature and its more formal setting differentiate it from the discussion group. The main advantage of the seminar as a mode of instruction is its stimulation and testing of students' powers of comprehension and evaluation. The presenter of the thesis from which the seminar stems is tested, in particular, on his skill in arranging and formulating a sustained argument. The seminar timetable must be prepared and explained to the presenter, it ought to allow for the following events;

\section{Introduction}

2. Presentation of the paper

3. Discussion -part I.

4. Interim summing-up.

5. Discussion-part II.

6. Summary of discussion (by tutor or member of class)

7. Replay to discussion.

8. Conclusion LB [13].

\section{Approaches of Conducting the Seminars in the Faculty of Medicine Suez Canal University}

The teacher centered seminar: At Faculty of Medicine, Suez Canal University (FOM-SCU), the seminars are unlike the conventional lecture style which is mostly one-sided talk, the discussions in the seminar are initiated and directed according to the questions and inquiries raised by the students. A panel of subject area experts from the disciplines related to the theme of the problem is invited to answer those questions. These multi-disciplinary contributions together with the encouraged students' participation proved to be highly stimulating and beneficial to all the attendants.

The new (innovative) students' centered seminar: In the academic year "2005-2006", FOM-SCU started to apply an innovative approach in conducting seminars, making students more involved in the process. Each week, one class (6-8 students) makes a presentation of the educational problem. This presentation consists of the theme of the problem, its definition, identification, objectives, and a summary. This presentation takes 30 minutes, where all the students in the class actively participate. Students gather information from up to date textbooks and from the internet (provided the internet references are reliable). An interactive discussion takes place where the students presenting the problem answer their colleagues' inquiries and their debating points under the supervision of the seminar moderator and subject area experts. This new approach to seminars is designed to incorporate principles of adult learning, where the learner has a central role in the educational process as someone who needs, wants and can learn through active participation.

\section{Significance of the study}

The significance of the study is that the school needs to evaluate the newly introduced students centered seminar; therefore, measuring students' satisfaction is a tool for its evaluation. Measure Kirkpatrick's evaluation of educational intervention level one.

The study has the following objectives:

- To measure students' satisfaction regarding the newly introduced students centered seminar and previously used teacher centered of seminars.

- To determined students' suggestions for further improvement in the students centered method of seminars.

- To identify students' opinions of changing the current method of conducting seminar into online seminars.

\section{Operational definitions}

Satisfaction: This shows a subjective impression, satisfaction user's, and the fulfillment of customers' requirements or needs, it also; an 
Citation: Marwa Ahmed AE, Wagdy TY, Refaat AH, El- Din Ahmed RAG (2014) Measuring Students' Satisfaction with Implementing a Student' Centered Seminar at Problem-Based Learning, the Faculty of Medicine - Suez -Canal University. Intel Prop Rights 2: 111. doi:10.4172/23754516.1000111

Page 3 of 6

organizational measure, usually by way of a survey, of the extent to which the needs and expectations of clients are met [14].

\section{Choice of educational methods}

Maintain congruence between objectives and methods: Choose educational methods that are most likely to achieve a curriculum's goals and objectives. One way to approach the selection of educational methods is to group the specific measurable objectives of the curriculum as cognitive, affective, or psychomotor objectives and selected educational methods most likely to be effective for the type of objective.

Use multiple educational methods: Individual have different preferences for learning, sometimes referred to as learning styles

(a) Some prefer to hear information, others to have visual aids, and others tactile aids. Some learners thrive with organization and structure: others learn well in an unstructured environment where they discover what is to be learned .Medical students have been shown to have different motivations for learning, such as passing then course, understand the material, or excelling, which affect the students' learning strategies or learning approaches.

The use of multiple educational strategies is particularly relevant in certain situations. For curricula that attempt to achieve complex objectives spanning several domains, the use of multiple educational methods is necessary to achieve congruence between objectives and methods.

Choose educational methods that are feasible in term of resources: Curriculum developers will need to consider faculty time, space, availability of clinical material and experiences, and costs, as well as the availability of learner time.

Faculty development may be an additional consideration, especially if an unfamiliar instructional method in chosen, such as role play or the use of multimedia. Use of technology, such as computer -assisted learning may involve initial cost but may save faculty resources over the time course of the curriculum [15].

What other factors shall we take into account when weighing benefits and disadvantages of various media? The main ones are: relationship to objectives, students learning preferences; the need for variety; availability/ accessibility, and cost [16].

\section{Kirkpatrick's four-level training evaluation model}

By far the most popular approach to the evaluation of training in organizations today is Kirkpatrick's [17] framework of four 'levels' of criteria. Kirkpatrick's $[17,18]$ training evaluation model delineates four levels of training outcomes: reaction, learning, behavior, and results.
The overwhelming popularity of the model can be traced to several factors (Table 1).

Customer satisfaction measurement: A process through which customer satisfaction criteria are set, customers are surveyed and the results interpreted in order to establish the level of customer satisfaction with the organization's product [19].

\section{Materials and Methods}

The study was a comparative one. Simple random sampling from Phase III students (4th, 5th and 6th year students') was selected a total number of 163 Students.

\section{Inclusion criteria}

Students who exposed to the teacher centered seminar (experts in different disciplines related to the weekly problem discuss and solve students inquiries about the difficult points in the problem), also who were taught by the students centered method students centered seminar; class presentation of the different objectives of the educational problem which occur under supervision of subject area experts in different disciplines. All males and females students were presented.

A Self-administered questionnaires for phase III students was distributed; measuring their satisfaction according two methods of implementing seminar students centered and teacher centered one. Items:

1. Students' perception of the knowledge of subject area experts.

2. Organization of the seminar.

3. Skills and abilities acquired by applying the students centered seminar.

4. Some other questions about certain parameters in the students centered seminars.

One part of the questionnaire was evaluated by rating scale starting from never, rare, sometimes, most of time and all the time weighting it $1,2,3,4$ and 5 respectively. The other part of the questioner with arsons of agrees or disagrees.

The designed questionnaires were reviewed by subject matter experts in the area of medical education for face validity, which refers to what a test appears to measure and not what it actually measures.

The questionnaires were redesigned according to the comments of the experts.

The reliability of these questionnaires was tested for internal consistency. Data were revised and then entered into microcomputer. SPSS software was used for the purpose of statistical analysis. Comparisons between students' satisfaction of the two methods of

\begin{tabular}{|c|l|l|}
\hline Level 1 & REACTION & $\begin{array}{l}\text { Participants' views on the learning experience, its organization, presentation, content, teaching methods, and } \\
\text { quality of instruction }\end{array}$ \\
\hline Level 2A & LEARNING_Change in attitudes & Changes in the attitudes or perceptions among participant groups towards teaching and learning \\
\hline Level 2B & $\begin{array}{l}\text { LEARNING_-Modification of } \\
\text { knowledge or skills }\end{array}$ & $\begin{array}{l}\text { For knowledge, this relates to the acquisition of concepts, procedures and principles; for skills, this relates to the } \\
\text { acquisition of thinking/problem-solving, psychomotor and social skills }\end{array}$ \\
\hline Level 3 & BEHAVIOR-Change in behaviors & Documents the transfer of learning to the workplace or willingness of learners to apply new knowledge \& skills \\
\hline Level 4A & $\begin{array}{l}\text { RESULTS-Change in the system/ } \\
\text { organizational practice }\end{array}$ & Refers to wider changes in the organization, attributable to the educational program \\
\hline Level 4B & $\begin{array}{l}\text { RESULTS-Change among the } \\
\text { participants' students, residents or } \\
\text { colleagues }\end{array}$ & Refers to improvement in student or resident learning/performance as a direct result of the educational intervention \\
\hline
\end{tabular}

Table 1: Kirkpatrick's model for evaluating educational outcomes. 
Citation: Marwa Ahmed AE, Wagdy TY, Refaat AH, El- Din Ahmed RAG (2014) Measuring Students' Satisfaction with Implementing a Student' Centered Seminar at Problem-Based Learning, the Faculty of Medicine - Suez -Canal University. Intel Prop Rights 2: 111. doi:10.4172/23754516.1000111

seminar were made using T-test (comparative statistics); mean and standard deviation used in reporting the results. The level of satisfaction was considered statistically significant at p-value less than 0.05 .

During the course of the study, some ethical considerations were followed, they were:

1. Obtaining a formal approval from Educational Sector of FOMSCU for documents review and collection of data.

2. All participants of the study were given explanation about the nature of the study.

3. All participants had the right to refuse to be included in the study.

4. Confidentiality of the responses of the participants was guaranteed by the anonymity of questionnaires.

5. Questionnaires were enveloped to keep confidentiality and privacy.

\section{Results}

The response rate was $91.5 \%$ (150 students) (Figure 1). The figure illustrates that $19 \%$ and $42 \%$ of the sample group in the old teacher centered method of seminar and students centered method students centered seminar respectively, said that they most of the time are keen to attend the seminar because of its importance to their understanding to solve the problem. Means for the two methods are close; the teacher centered method mean \pm SD is $2.85 \pm 0.53$, while the students centered method mean \pm SD $3.17 \pm 0.75$. There is a statistically significant difference ( $p$-value $<0.05$ ). The figure illustrates that $7 \%$ and $21 \%$ of the sample group in the teacher centered method of seminar and students centered method of seminar respectively, said that seminar is conducted in a discussion form. Means for the two methods are different; the teacher centered method mean \pm SD is $2.87 \pm 0.16$, while the students centered method means \pm SD is $4.09 \pm 0.82$. There is a statistically significant difference ( $\mathrm{p}$-value $<0.0001$ ) between two methods (Figure 2 ). The teacher centered method Mean \pm SD is $2.87 \pm 0.16$

Table 2 shows that students acquired new skills by applying the new innovative approach in conducting seminars. There is statistically significant difference ( $\mathrm{p}$-value $<0.0001$ ) between two methods regarding students' acquisition of leadership skill, presentation skill and communication skills.

Table 3 (Significant p- value $<05$ ) shows that students acquired new abilities by applying the new innovative approach in conducting seminars. There is statistically significant difference ( $\mathrm{p}$-value $<0.0001$ ) between two methods regarding students' ability to Search in the internet, Express their points of view, and Use additional educational resources.

Table 4 illustrates that: Eighty five percent of the students learned by the students centered method of seminar agreed that their presentation skills are in need for improvement. Sixty four percent of the students learned by the students centered method of seminar agreed that their computer skills are in need for improvement. Sixteen percent of the students learned by the students centered method of seminar agreed that their presentation in the seminar should be evaluated and be part of their summative assessment. Thirty nine percent of the students learned by the students centered method of seminar agreed that changing the current method of conducting seminar into on line seminar will be better.

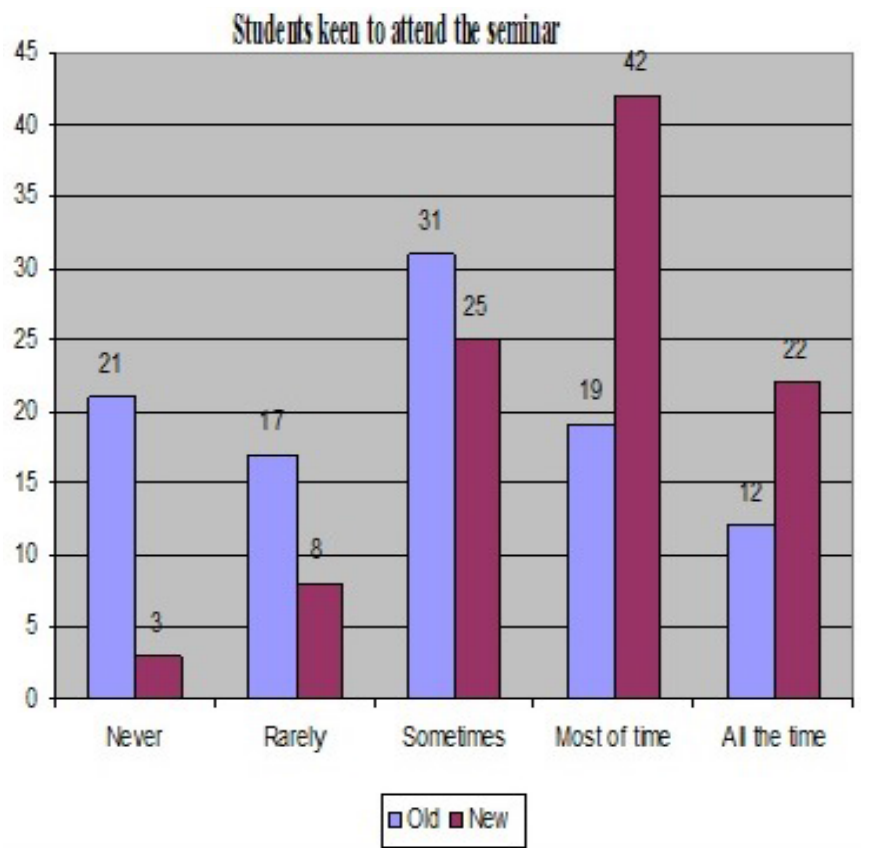

Figure 1: The percentage of Students' response regarding their keen to attend the seminar because of its importance to their understanding to solve PBL problem.

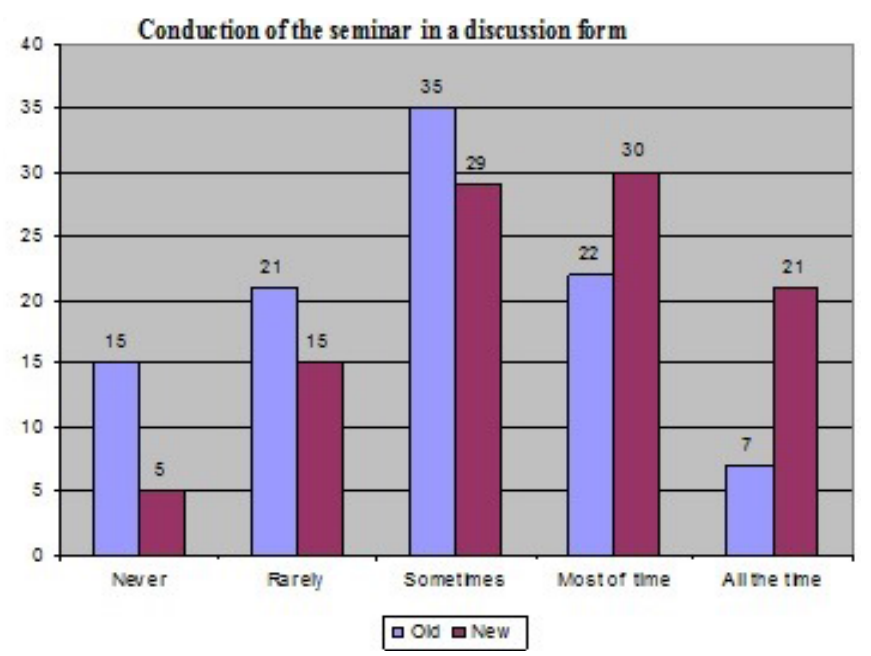

Figure 2: The percentage of Students' response regarding conduction of the seminar in a discussion form.

\section{Discussion}

A weekly seminar with a theme related to the weekly problem is one of the major and most important educational activities held at the FOM-SCU for each of the six school years. In 2005, FOM-SCU conducted a self-study that evaluated the educational resources among the other services and activities. This evaluation showed that only $29.8 \%$ of students thought seminars were very useful. Based on the previous results, in the academic year "2005-2006", FOM-SCU started to apply an innovative approach in conducting seminars, making students more involved in the process. Each week, one class makes a presentation of the educational problem. This presentation consists of the theme of the problem, its definition, identification, objectives, and 
Citation: Marwa Ahmed AE, Wagdy TY, Refaat AH, El- Din Ahmed RAG (2014) Measuring Students' Satisfaction with Implementing a Student Centered Seminar at Problem-Based Learning, the Faculty of Medicine - Suez -Canal University. Intel Prop Rights 2: 111. doi:10.4172/23754516.1000111

Page 5 of 6

\begin{tabular}{|c|c|c|c|c|}
\hline $\begin{array}{c}\text { Acquired skills by the } \\
\text { seminars }\end{array}$ & $\begin{array}{c}\text { Students Centered } \\
\text { Seminar }\end{array}$ & $\begin{array}{c}\text { Teacher } \\
\text { Centered Seminar }\end{array}$ & T Test & P-value \\
\cline { 2 - 5 } & Mean \pm SD & Mean \pm SD & & \\
\hline Leadership skills & $2.67 \pm 0.51$ & $3.96 \pm 0.91$ & 15.1 & $0.0001^{*}$ \\
\hline Presentation skills & $2.67 \pm 0.51$ & $3.96 \pm 0.91$ & 15.1 & $0.0001^{*}$ \\
\hline Communication skills & $2.77 \pm 0.49$ & $3.71 \pm 0.57$ & 15.3 & $0.0001^{*}$ \\
\hline
\end{tabular}

Table 2: Students' new skills acquired by the Seminars.

\begin{tabular}{|l|c|c|c|c|}
\hline \multirow{2}{*}{$\begin{array}{l}\text { Students' abilities acquired by } \\
\text { the seminar }\end{array}$} & $\begin{array}{c}\text { Students } \\
\text { Centered } \\
\text { Seminar } \\
\text { Mean } \pm \text { SD }\end{array}$ & $\begin{array}{c}\text { Teacher } \\
\text { Centered } \\
\text { Seminar } \\
\text { Mean } \pm \text { SD }\end{array}$ & T Test & P-value \\
\hline Gain self confidence & $2.82 \pm 0.34$ & $4.02 \pm 0.63$ & 20.5 & $0.0001^{*}$ \\
\hline Search in the internet & $2 \pm 0.42$ & $3.72 \pm 0.7$ & 16 & $0.0001^{*}$ \\
\hline Express their points of view & $2.73 \pm 0.44$ & $3.74 \pm 0.89$ & 18.3 & $0.0001^{*}$ \\
\hline $\begin{array}{l}\text { Acquire new updated evidenced } \\
\text { based information related to the } \\
\text { problem }\end{array}$ & $2.87 \pm 0.23$ & $3.74 \pm 0.89$ & 11.6 & $0.0001^{*}$ \\
\hline $\begin{array}{l}\text { Use additional educational } \\
\text { resources }\end{array}$ & $2.79 \pm 0.21$ & $3.08 \pm 0.75$ & 4.6 & $0.0001^{*}$ \\
\hline
\end{tabular}

Table 3: Students' abilities acquired by the seminars.

\begin{tabular}{|l|c|c|c|c|}
\hline Agreement or disagreement of Students with & \multicolumn{3}{|c|}{ Agree } & \multicolumn{3}{|c|}{ Disagree } \\
\cline { 2 - 6 } $\begin{array}{l}\text { certain parameters regarding the new approach of } \\
\text { conducting seminar }\end{array}$ & No. & $\%$ & No. & $\%$ \\
\hline The presentation skills are in need for improvement. & 127 & 85 & 23 & 15 \\
\hline The computer skills are in need for improvement. & 96 & 64 & 54 & 36 \\
\hline $\begin{array}{l}\text { The presentation in the seminar should be evaluated } \\
\text { and be part of students' summative assessment. }\end{array}$ & 24 & 16 & 126 & 84 \\
\hline $\begin{array}{l}\text { Changing the current method of conducting seminar } \\
\text { into on line seminar will be better. }\end{array}$ & 58 & 39 & 92 & 61 \\
\hline
\end{tabular}

Table 4: Students' opinions about certain parameters in the new innovative methods of conducting seminar.

a summary. This presentation takes 20 minutes, where all the students in the class actively participate. Students gather information from up to date textbooks and from the internet (provided the internet references are reliable). An interactive discussion takes place where the students presenting the problem answer their colleagues' inquiries and their debating points under the supervision of the seminar moderator and subject area experts. This new approach to seminars is designed to incorporate principles of adult learning, where the learner has a central role in the educational process as someone who needs, wants and can learn through active participation.

Only $19 \%$ of students were keen to attend the teacher centered method of seminar regardless of attendance recording, compared to $42 \%$ in the students centered method. This difference in attendance rate might be due to the lack of interest of students in the teacher centered method as it was not applied as planned since the foundation of the faculty. This shows that students prefer the students centered method and feel it is more productive and helps them understand and solve the problem. The students centered method also motivates students to work on the problem and find interesting ways of presenting it, owing to the new spirit of challenge among them.

Scott B [20] reported that the staff members on instruction on the Internet approach accentuate the "student as worker" and the "teacher as coach" paradigms. The role of the staff members becomes one of anticipating the needs of the students in advance and providing contingencies. They become Socratic questioners, resource providers and motivators. Instructors respond to and accommodate learners in assisting them to develop their own meaning for the material rather than interpreting the material for them. It poses a real challenge to traditional thinking, or at least traditional practice. Brunton et al. [21] in their study stated students were enthusiastic to control, own and manage their individual learning experiences and look to members of staff to facilitate rather than manage the learning process.

Concerning the process, $7 \%$ and $21 \%$ of the sample group in the old method of seminar and new method of seminar respectively, said that seminar is conducted in a discussion form all the time, the old method mean was $2.87 \pm 0.16$, while the new method means was 4.09 \pm 0.82 .There is a statistically significant difference ( $\mathrm{p}$ value $<0.001$ ). This is consistent with the results of Abu-Zidan and Windsor [22] which showed seminars to be interactive with least squares mean of 4.04 and $p$ value $=0.008$. Greater use of student learning (self-directed) opportunities, in the form of discussion groups with members of staff, postgraduate students or in certain circumstances participating students facilitating the learning process, is to be encouraged. Discussion is an active process of students -teacher involvement in the seminar. Discussion allows a students to discover and state a personal opinion and not merely repeat that which the teacher or text already presented [23].

Medical teachers most of whom are taught in traditional paradigm and have little exposure to many innovative teaching and learning methods. in FOM-SCU, they used to change seminar into a traditional lecture. Attending lecture is analogues to attending a play, the audience's role is to enjoy the play and appreciate the actors. The audience is not expected to interrupt the play nor questions the actors. The passivity of the students during lecture contradicts the practice of learner-centered leraning approaches.

So new method of seminar with the active form of discussion between students and their peers and between students and staff members transforms them from passive form of teaching to more active and interactive form of learning, its importance is fittingly described by ancient chinese proverb that said "I hear and I forget, I see and I remember, I do and I undestrand".

In our study, the questionnaire investigated that the seminar helps students to express their points of views. The old method mean was 2.73 , while the new method mean was 3.75 . This difference was significant $\mathrm{p}$-value $<0.0001$. The seminar also helps students gaining self-confidence. The old method mean was 2.82 , while the new method mean was 4.02 and the difference was statistically significant $(p<0.0001)$. in this context, Brunton et al. [21] stated that It was possible that rotating the leader of the clinical seminars between members of the group, thereby increasing confidence, could reduce the difficulty some students reported in respect of contributing to the discussion.

\section{Recommendations}

The study recommends the following

\section{For curriculum}

1. The integration of Information and communication technology (ICT) not only changes traditional styles of pedagogy and instructional techniques, but also gives students opportunities to require the degree of computer literacy they will need in their later professional life.

2. Integration of new courses in the curriculum about communication skills, presentation skills, computer skills and elementary Internet tasks.

3. The introduction of computer-supported PBL that influence 
Citation: Marwa Ahmed AE, Wagdy TY, Refaat AH, El- Din Ahmed RAG (2014) Measuring Students' Satisfaction with Implementing a Student' Centered Seminar at Problem-Based Learning, the Faculty of Medicine - Suez -Canal University. Intel Prop Rights 2: 111. doi:10.4172/23754516.1000111

Page 6 of 6

students' approaches to learning. This needed computersupported learning environment. There is an obvious need for computer-based learning material in medicine. In the future, more attention should be paid to instructional procedures, implementation and evaluation. Universities should, in addition to technical skills, also take care of pedagogical knowledge. This is of great importance because modern technology and digital learning environments allow different kinds of learning processes. Medical teachers need to be able to meet these challenges and act in an appropriate way, using methods which enhance both teachers and medical students' ways of learning.

4. Training of medical students on principals of Evidence-Based Medicine including:, how to search the internet for medical information, critical appraisal of studies. And self -evaluation of their information retrieval process.

5. Evaluate all the educational resources in depth.

\section{For Staff members}

1. Introducing seminar moderators to new concepts such as communication skills, group dynamics, and adult learning, further attention should be paid to training Staff members to function as more active moderators.

\section{For students}

1. Training to medical students about how to use Web-based search tools and techniques in order to find high-quality information resources. Also training medical students on the skills required for e-learning; information processing and information technology and Information-searching. Increase students' abilities to deal with the growing information load and to adapt to an ever-changing working environment.

2. Encourage students to use FOM-SCU computer unit with is already supplied by the internet, for searching updated, reliable and evidence based information.

3. Developed an evaluation checklist to the presentation, so that students know how their presentation is evaluated and how they perform well in it.

4. Design and distribute certificate of honor the class, which make the most skillful scientific presentation, challenging its students to actively participate, and to work in a team.

\section{Conclusion}

Study conclude that the students generally preferred the students centered method of conducting the seminar more than the teacher centered as they fell more responsibility for it, and more actively involved in it, also they are active learner, they search for the updated information related to the theme of the problem try together to work in a team, benefit from each other and using their skills and abilities to present the weekly problem in a competitive, challenging spirit between them. This makes them more satisfied by the students centered method of conducting seminar. The students not yet ready for the online learning as they did not have the required skills to run it, they did not agreed to change the current seminar into online seminars.

\section{References}

1. Albanese MA, Mitchell S (1993) Problem Based Learning: A Review of Literature in Its Outcomes and Implementation Issues. Acad Med 68: 52-81.

2. Jones RO, Donnelly MB, Nash PP, Young B, Schwartz RW (1993) The Ongoing Development of A Problem-Based Surgery Clerkship: Year Three. Medical Teacher 15: 207-215.

3. Neufeld VR, Barrows HS (1974) The McMaster Philosophy: an Approach to Medical Education. J Med Educ 49: 1040-1050.

4. Dolmans DH, De Grave W, Wolfhagen IH, van der Vleuten CP (2005) Problembased learning: future challenges for educational practice and research. Med Educ 39: 732-741.

5. Maudsley G (1999) Roles and responsibilities of the problem based learning tutor in the undergraduate medical curriculum. BMJ 318: 657-661.

6. Peterson M (1997) Skills to Enhance Problem-based Learning. Med Educ Online.

7. Maklady F, Talaat W, Saleh M, Moghazy A, Khamis N et al. (1998) Document on the Faculty of Medicine, Suez Canal University (FOM-SCU). Suez Canal University Press.

8. Rankin JA (1992) Problem-based medical education: effect on library use. Bull Med Libr Assoc 80: 36-43.

9. Premkumar K, Baumber JS (1996) A learning resources centre: its utilization by medical students. Med Educ 30: 405-411.

10. Eid Ragaa (2002) Some teaching methods. Suez Canal University Press, Egypt.

11. Six Sigma Dictionary

12. Smith JO (1974) Development of the self-instructional materials Learning Resources Center. Bull Med Libr Assoc 62: 417-420.

13. L.B Curzon (2004) Teaching in Further Education, an Outline of Principles and Practice. Bloomsbury Academic.

14. Nielson J (1993) Usability Engineering. Nielsen Norman Group.

15. Kern DE, Thomas PA, Donna MH, Eric BB (1998) Curriculum Development for Medical Education. A Six step Approach. 5: 38-53.Baltimore, Maryland, USA.

16. Rowntree D (1981) Developing courses for students. England 142: 174 -177.

17. Kirkpatrick, D (2006) Evaluating Training Programs: The Four Levels. BerrettKoehler Publishers.

18. Kirkpatrick D, James DK (1997) Evaluating Training programs, The four Levels Berrett-Koehler Publishers.

19. John F, David J (2012) Foundations of Marketing. McGraw-Hill Education, Europe.

20. Scott BW (1999) The Effects of Internet-Based Instruction on Student Learning Southwest Missouri State University, JALN.

21. Brunton PA, Morrow LA, Gillian HR, J Fraser McCord, Nairn HFW (2000) Students' Perceptions of Seminar and Lecture-Based Teaching in Restorative Dentistry. Eur J Dent Educ 4: 108-111.

22. Abu-Zidan FM, Windsor JA (2001) Students' Evaluation of Surgical Seminars in a Teaching Hospital. Med Educ 35: 673-680.

23. Amin Z (2004) Medical Education in Asia: Is it a Time for Optimism? Annals Academy of Medicine 33: 264-266. 